\title{
39. ベンチオカーブのイネ・ヒエ间における遙扶㪊草性譏構。
}

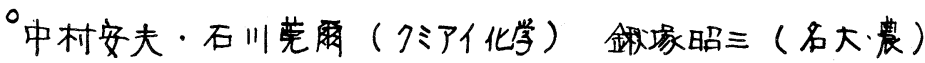

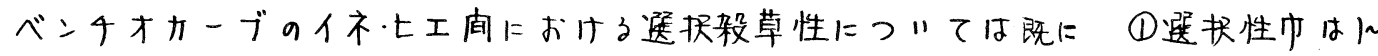

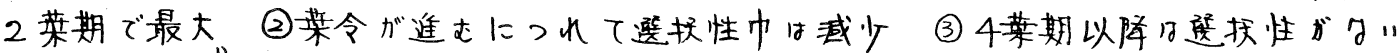

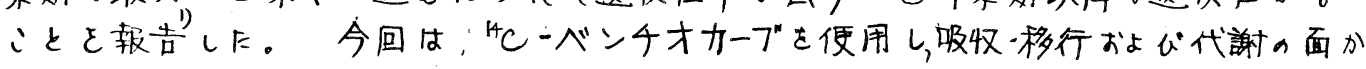

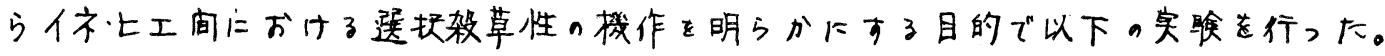

\section{(方法)}

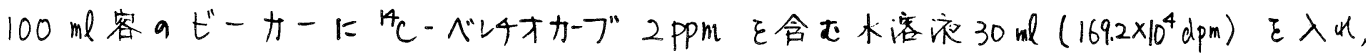

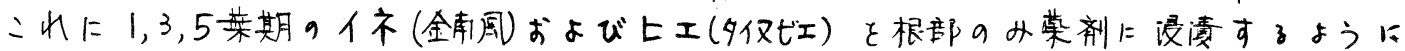

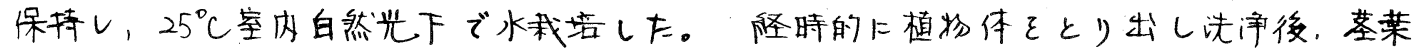

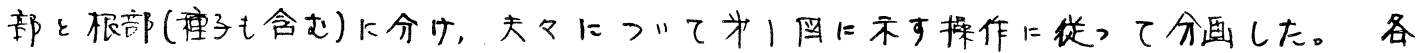

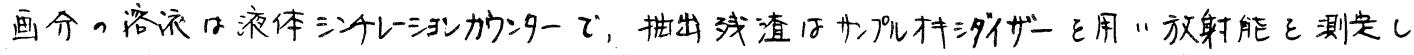

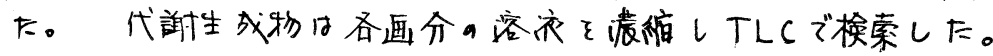

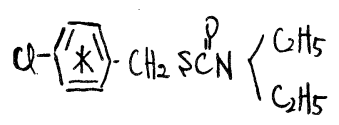

14C・槚誡べレ4オカーブ（ 3.21 mai $/$ m.nole $)$

(結果および考鉒)

1)イネ・上エにおける吸収上移行。

各葉期のイネおよで上工の根から吸收さ 以下放射能量的变化を为2国下示す。

川ずれの植物体毛比較的速书かに根から ベレチオカーブを吸収したが，单位生体重あた リの吸収量で比較すると，葉期の上工が 最 $t$ 多<，ついで菜期の上工，1荣期の イネ，3，5菜期のイネと5菜期の上工の順 であ、下。

根から坴莱部に移行した量をオる因に市

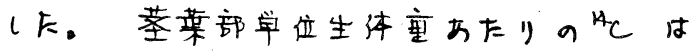
|菜期の上エで影著に多く,ついでろ荣期 の上工，各菜期のイネおむび5荣期の七工の順であつた。

シ小ら得られた咭果が教草活性、大小と良く一致していることから，根からの吸収

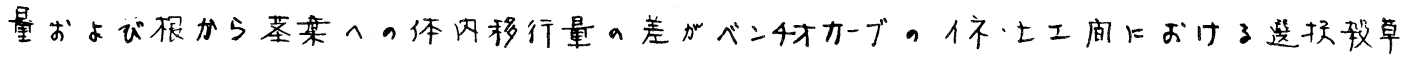
性の人つの要田と吅ることが推察される。

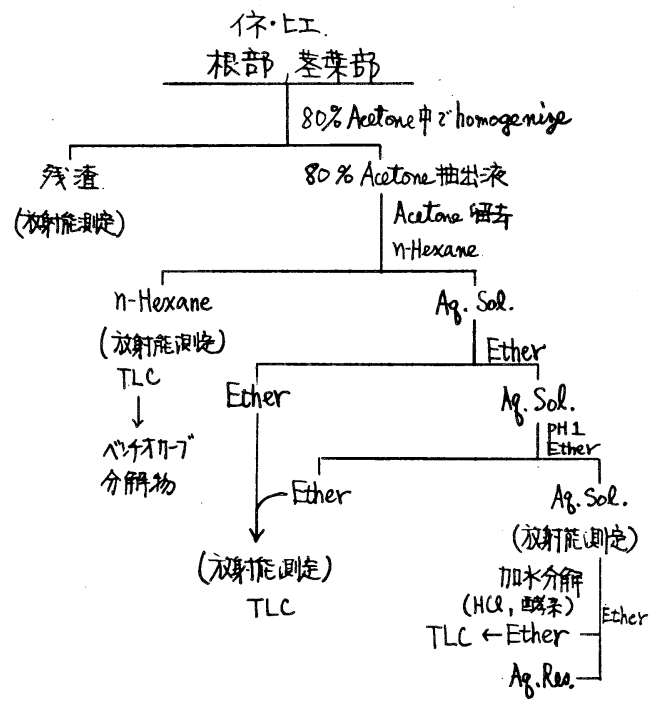

米图抽出法, 7ローシート 


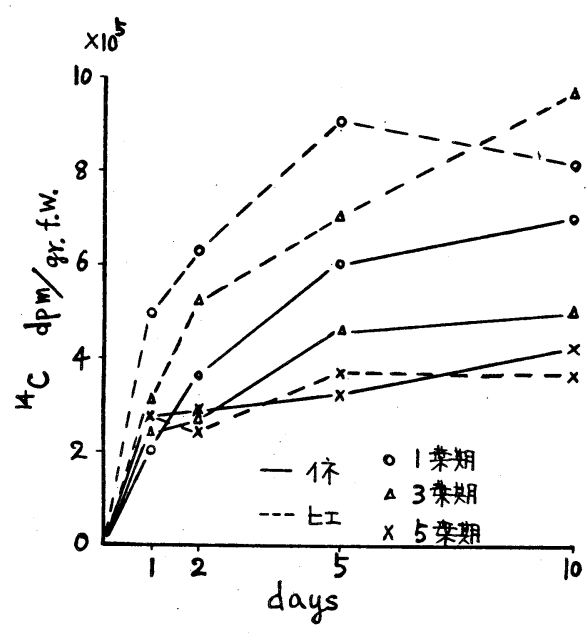

才2因水耕液がら ${ }^{14} \mathrm{C}$ 吸收 (植物体全体)

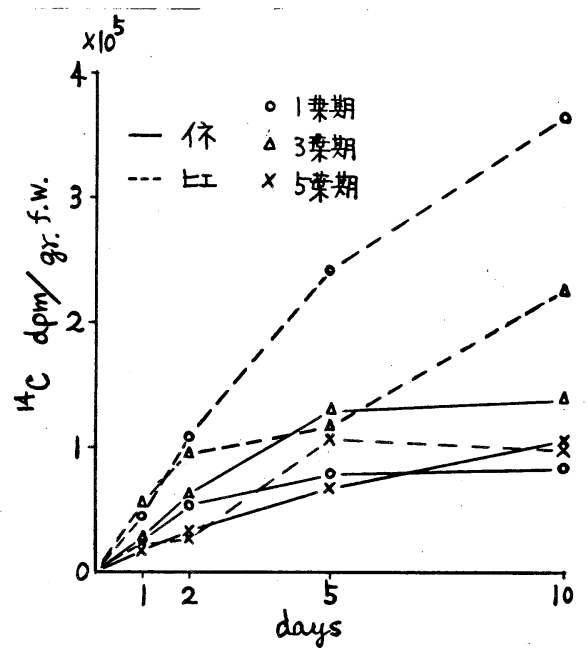

米了図根部吸收による茎葉への移行

2) 代謝

(a)ベンチオカーブの代謝速度

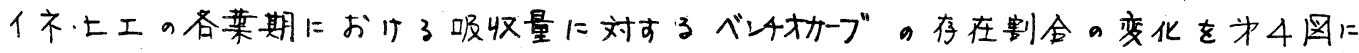
示した。|来期をみると，イネでは速やかに減少するが，上エでは䋸慢的减少を不

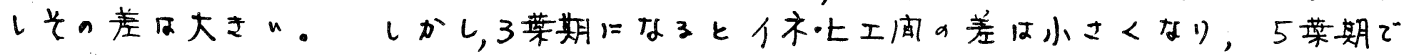
は同し推移を示しF。: 、のベンチオカーブ、存在制合の变化を代谢速度上考之ると。

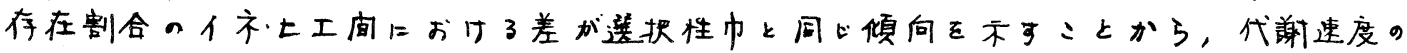

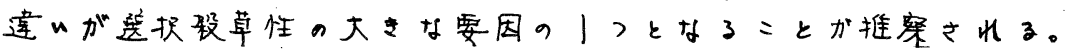

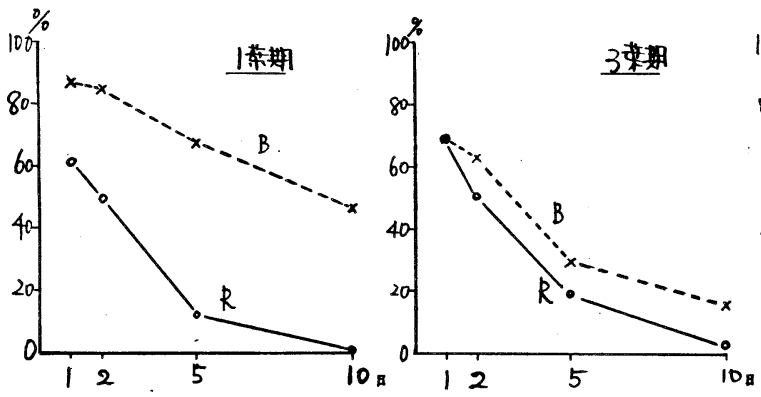

米4四。吸収量に対するベレ4オカーブ、存在剿合、消長

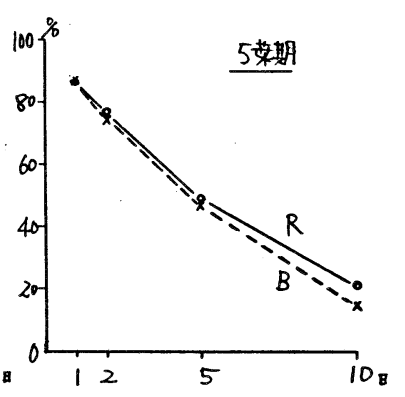

$R:$ R $\quad B: E I$ (植物体全体)

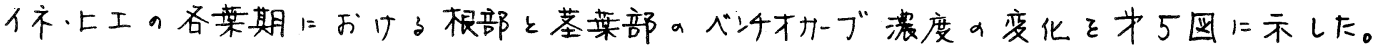

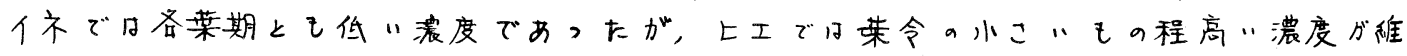

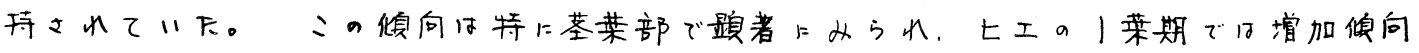

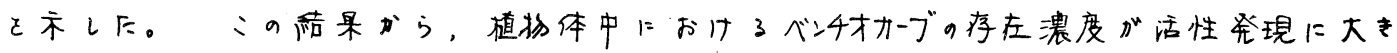
く用与しでるものと思われる。 

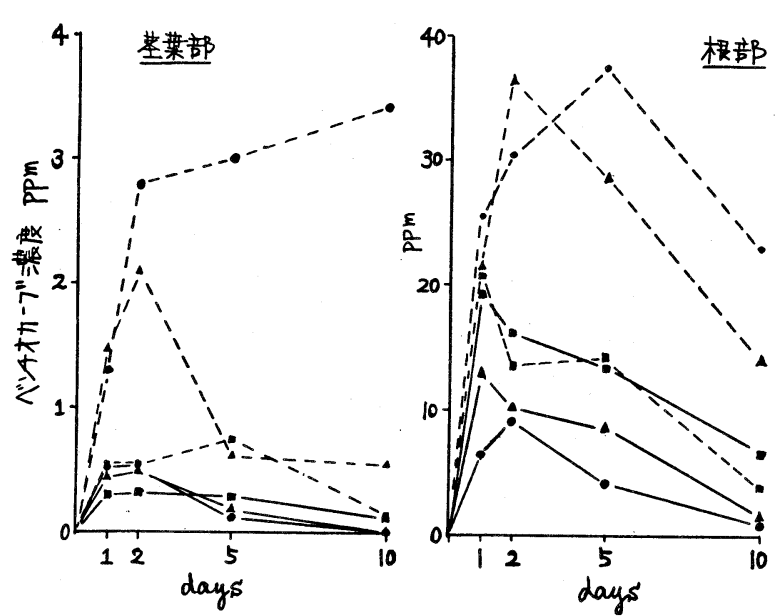

斗5図ベ・チオカーブ濃度の消長

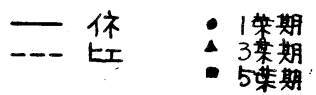

(b) 代謝生成物口分㒕上消長

为人国三示榇作に徙叭画し下各画分での ${ }^{14}$ Ca推移を詞べた。代表例飞して1葉期の作 上エにつ"て各画分a ${ }^{14} \mathrm{C}$ 存在剖合a变化を斗 6 因 に示す。ベンチオかーブが減少し、关れにつれて，水 画分およ抽出残查の剖合”增加した。ミの倪

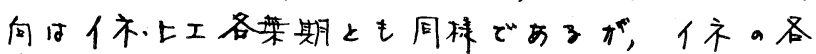
禿期飞上エの 5 葉期で频著であ，た。

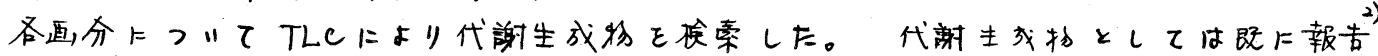

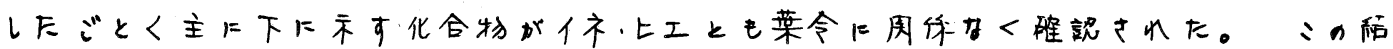

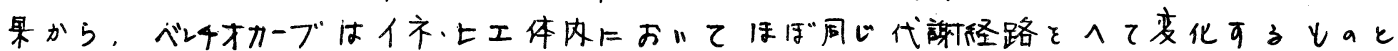
思内的る。

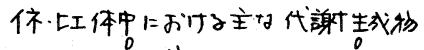

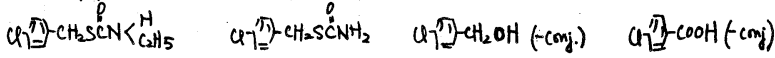

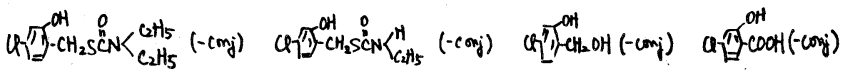

以上の結果から，吸収量、体风移行量がび代謝速度に基ぶくベレチオカーブの体内存

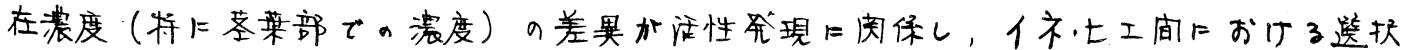
刹草性の因の)部になつているものと推定した。

1) 日本雑草防除研究会为8回譜演要旨 $P .9$ (1969)

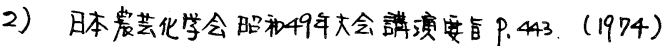


目的

40. エチレン発生阻害蛋白のホルモン型除草剂による薬害防止につい 滒埸 起・酒井慏吾（周山大農菜生物研）

オーキシン（ＩＡＡ）やオ一キシン系除草剂による生長阻害，分げつ抑制，上偏生

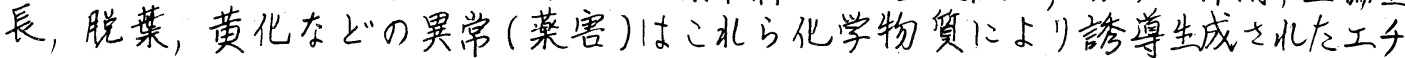
レンによる障害であることがほぼ明らかとなつた。最近今南・酒井（1973）は，ヤ 工十り芽生えの肧軸から分敨生し太水溶性蛋白（分子量１/万2千）は才一キシンによ リ誘導さ北るエチレンの発生を阻害することを発芫した。本研究では，うの水溶性 蛋白の農菜つの利用克目標として，該蛋白の才一キシン系除草剂による薬害防止 の勒果に圈して研究を行つた。

实験方法および結果

（才一实験）移植後の水榴における才一キシン系除草剂の薬害防止効果

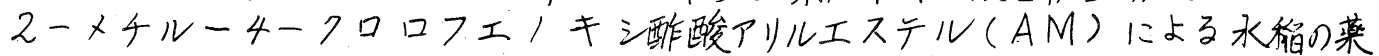
害に対する工チレン発生阻害蛋白の効果走しらべ。温室における24分の/アール ポツトを用いた土壤鉢武駼で利|表のような区别走設けて实駼を行つた。4月15日草大 約15 cm の苗を1鉢了本植に移植した。草丈20 cm になつた4月23日AM水和剂の 水分散液圭土面処理した。5月14日にAM処理区の水稻に，才一キシン系除草剂処理

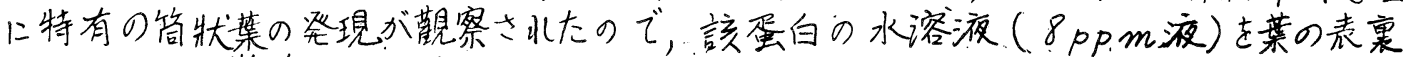
西面に丁然に散布した。蛋白液無散布の区には礼水を散布した。

矛ノ表のように，筒状葉の発現は，ANの処理量にかかわらず蛋白液散布で減少し 太。なお简狀莱は，蛋白無散布区では弱小分げつばかりでなく，主稈や大きな分げっ にも発現したが、蛋白液散布区ではおもに弱小分げつに発現した。また矛に表のよう に各区の间で草大には差が少なかつたが，茎数は，蛋白液散布で手取，AM少量，A

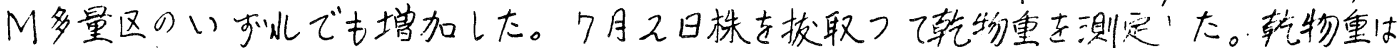
いづ将の処理区でも宪加したが，その增加は，手取除草くAM少量くAM多量の順 に大きかった。

为1表蛋白液散布による水稻生育の差異

\begin{tabular}{|c|c|c|c|c|c|c|c|}
\hline \multirow[b]{2}{*}{ 区 别 } & \multicolumn{3}{|c|}{5 月 $21 日$} & \multicolumn{3}{|c|}{6 月 4 日 } & \multirow{2}{*}{$\begin{array}{c}7 \text { 月 2日 } \\
\text { 乾物重 } \\
\mathrm{g}\end{array}$} \\
\hline & $\begin{array}{l}\text { 草丈 } \\
\mathrm{cm}\end{array}$ & $\begin{array}{c}\text { 茎数 } \\
\text { 本 }\end{array}$ & $\begin{array}{l}\text { 筒状菜 } \\
\text { 発生荎 } \%\end{array}$ & $\begin{array}{l}\text { 草丈 } \\
\mathrm{cm}\end{array}$ & $\begin{array}{c}\text { 茎 数 } \\
\text { 本 }\end{array}$ & 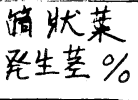 & \\
\hline 手取除草 & 52.8 & 18.5 & 0 & 63.6 & 19.5 & 0 & 20.18 \\
\hline "十蛋白液散布 & 53.2 & 19.5 & 0 & 62.3 & 20.5 & 0 & 22.15 \\
\hline$A M / 5 \mathrm{~g} / \mathrm{a}$ & 55.0 & 17.0 & 23.5 & 60.4 & 18.5 & 16.2 & 19.98 \\
\hline "十蛋白液散布 & 52.1 & 17.5 & 20.0 & 60,4 & 20.0 & 7.5 & 22.94 \\
\hline$A M 10 g / a$ & 51.5 & 14.0 & .53 .6 & 59.8 & 18.5 & 45.9 & 17.19 \\
\hline "十蛋白液散布 & 50.5 & 16.5 & 42.4 & 64.8 & 19.0 & 21.1 & 20.98 \\
\hline
\end{tabular}

(注) 1 区2鉢。肥料: 化成肥料( $15: 15: 15) 3 \mathrm{~g} /$ 金本。水稻品種: ヤマビコ

(句二实験) 移植苗に対する蛋白液散布の才一キシン系除草剂による菜害の防止効果 


\section{( A Mの場合)}

移植苗に対する蛋白液散布がAMによる薬害を防止する効果をみる太めに，温室に おいて5チ分の1アールポツトを用い, 蛋白液散布区上蛋白液無散布区を設けて武駼

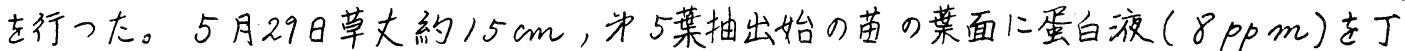
寕に散布し、こ北を/ポツト了本宛に移植した。蛋白液無散布区では紈水を散布し太。 移植翌日95月30日A M 水和到の水分散液吉所定量( $10 \mathrm{~g} / \mathrm{a})$ 土面处理した。

移植後は两区の水稳に゙生育の差がなかつ太が，6月20日頃から蛋白無散布区に筒状 葉が現儿、7月4日の調查では弟2表のように蛋白液散布により草丈，茎数が增加し， 生存菜数毛やや多く夺つた。1区2鉢。

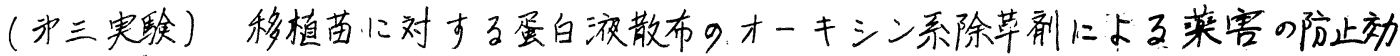
果 (2,4-Dアミンの場合)

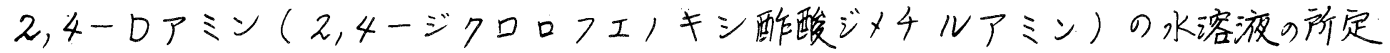

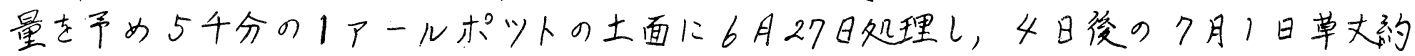
$20 \mathrm{~cm}$, 武6 某未展南の苗の某面に蛋白液( 8 p p m ) 散布および紝水散布( 蛋白無散 布区)圭行ない, 乙北をはポツトに4本宛移植した。2,4ーDアミンの使用量はアー 儿当り4.1 g およで8.2 gの2段階とした。1区2钵。实駼は硝子室で行つ太。

7月22日生育調查の結果は为2表のように，2４４一D量のいか人にか力わらず茎数 は蛋白液散布で增加し, 草丈も2,4一D多量区では蛋白液散布でや〉大となった。简 状菜の発生数手蛋液散布で㨔少した。

司2表移植苗上对寸了蛋白液散布による水榴生育の差異

\begin{tabular}{|c|c|c|c|c|c|}
\hline 实 馬㑒 & $区$ & 草 $\underset{\mathrm{cm}}{\mathrm{X}}$ & ${ }_{\text {荎本 }}^{\text {数 }}$ & 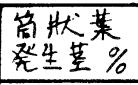 & $\begin{array}{l}\text { 主茥生 } \\
\text { 存菜数 }\end{array}$ \\
\hline 車 二 & $\begin{array}{l}\text { AM } 10 \mathrm{~g} / \mathrm{a} \\
\text { "十蛋白液散布 }\end{array}$ & $\begin{array}{l}35.8 \\
39.6 \\
\end{array}$ & $\begin{array}{l}2.15 \\
2.30\end{array}$ & $\begin{array}{r}38.10 \\
2.95\end{array}$ & $\begin{array}{l}3.40 \\
3.50\end{array}$ \\
\hline 辛 三 & $\begin{array}{c}2,4-D 4.1 \mathrm{~g} / \mathrm{a} \\
" \text { 十蛋白液散布 } \\
2,4-D 8.2 \mathrm{~g} / \mathrm{a} \\
" \text { 十蛋白液散布 }\end{array}$ & $\begin{array}{l}64.5 \\
64.7 \\
63.7 \\
65.3 \\
\end{array}$ & $\begin{array}{l}5.00 \\
5.50 \\
4.50 \\
5.60 \\
\end{array}$ & $\begin{array}{c}2.5 \\
0 \\
28.8 \\
2.3 \\
\end{array}$ & \\
\hline
\end{tabular}

考察

(注)肥料: 化成( $15: 15: 15) 2 \mathrm{~g} /$ ポツト, 元肥, 皿種:ヤマビコ

本实験は基礎的段階のものであり，本剂の实用化のためには圈場使用の場合の剂の 勃力の持続性なよび安定性，剂形，展着剂の问題等多くの巵用化およで实用上の諸古， 題点の解決が必要である。

しかし從来天候や使用法の誤りなどの荓係でオーキ之ン系除草剂の菜害が起つ太場 合あるいは起るおていがある場合に適切夻対策がなかつたが，本蛋白の菜害防止軽减 の勃果が期待できよう。

またオーキシン系除草矵は菜害の発生等念して，生育の中期以後に多く使用を北 ているが、本蛋白の利用により使用の時期の拡大が期待できよう。 
41. Naphthalic anhydride 抄よu゙ R-25788の薬害軽减効果に ᄀい?

西静雄，佐合隆一，近藤俊夫，足立明朗

$$
\text { ( 全農農業技術センタ一) }
$$

且的除草刹は雑草の砥除を目的として使用されるが、同じ高等植物である作物に 対しては莧害がるく安全でなりればるらない。雅草と作物との間の除草剂の選択作用

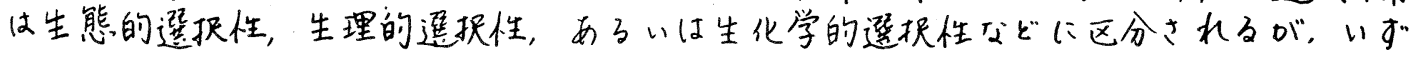
れも絶対的なものでなく、除草剂の使用にあ下っては、下元蔡害の危険が伴ってい

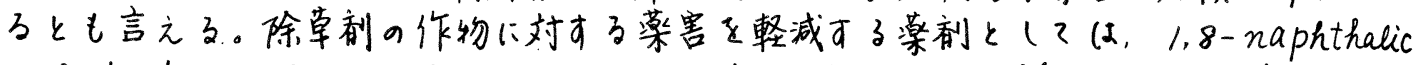
anhydride ( $N A)$ ) s 2 C゙ R-25788 ( $N, N$-diallyl-2,2-dichloroacetamide :DDAA) がトラモロコシに対する数種の除草绪の薬害を埾减す了効果があると報告されている。 演者らは、これら軽减剂がイネに詨しても効果があるかどうかについて若千の検討を

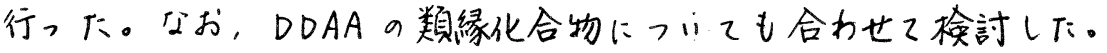

\section{㭝料书よ污方法}

\section{( 材料)}

軽减剂

Naphthalic anhydride $(N A)$ : 試蔡( 和光純蔡製)

$N . N$-diallyl-2, 2-dichloroacetamide(DDAA) おょci゙の類縁化合物:A,J, Speziale らの方法により下記により合成した。

$$
\begin{aligned}
\left(\mathrm{CH}_{2}=\mathrm{CH}-\mathrm{CH}\right)_{2} \mathrm{NH}+\mathrm{Cln} \mathrm{CH}_{3-n}-\mathrm{COCl} \frac{\mathrm{NaOH}}{1,2-\text { dichloro ethane(冷却) }} \\
\quad\left(\mathrm{CH}_{2}=\mathrm{CH}-\mathrm{CH}_{2}\right)_{2} \mathrm{~N}-\stackrel{\mathrm{C}}{\mathrm{C}}-\mathrm{CH}_{3-n} \mathrm{Cln}
\end{aligned}
$$

$n=1: C D A A, n=2: D D A A, n=3:$ TDAA

上記軽减刘は $40 \%$ 水和剂に製剂( 亿試験に供試いた。

除草剂

$$
\begin{aligned}
& \text { モり衤一ト： } 70 \% \text { 乳剂 } \\
& \text { CNP : } 10^{-2} M \text { 工夕口ール溶液 } \\
& \text { オキサジァゾン：12\%乳靔 } \\
& \text { EPTC : } 75 \% \text { 乳剂 } \\
& \text { ANK-553 (N-(1-ethyl propyl)-2,6-dinitro-3,4-xylidine): } 30 \% \text { 乳剂 }
\end{aligned}
$$

(方法) イネ(日本晴) およU゙ヒエ（タイヌビエ）㮔子を催芽後 径 $9 \mathrm{~cm}$ 高さ $2 \mathrm{~cm}$

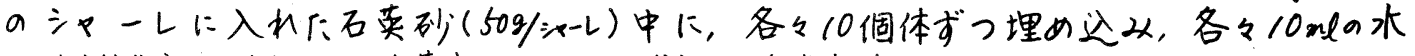

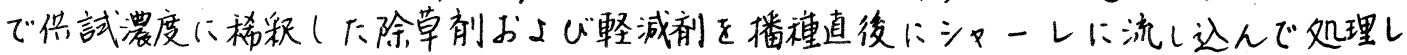

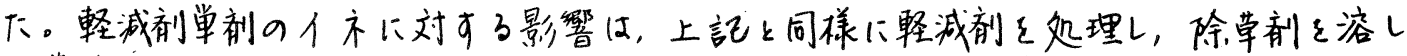

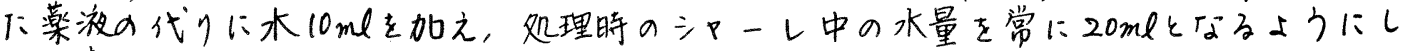
下。薬剂処理後, シャ一レは絢2500lxa照明(16時間照明/日) a $25^{\circ} \mathrm{C}$ 恒温室に放

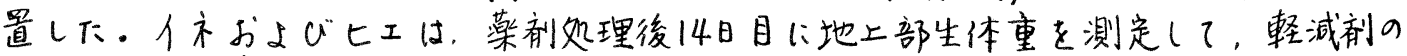
イネに対する蔡害軽减効果と同時に七エに対す了除草剂の殺草性へ9影響を調べた。 
菜害軽减効果は次式により算出し, 指数で判定した。

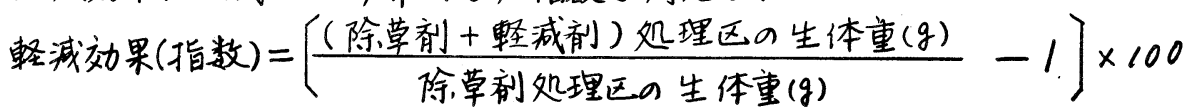

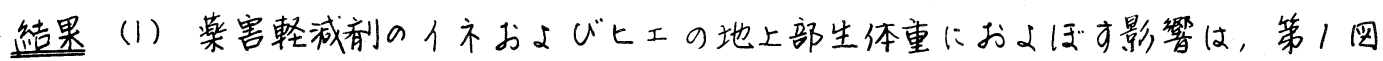

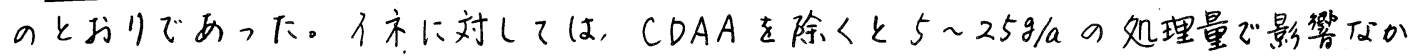
った。一方七エに対しては，CDAAを除くと5g/aの処理量で影響てかったが, $25 \mathrm{~g} / \mathrm{a}$

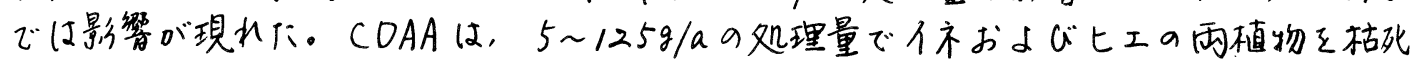
させ下。

(2) 供試除草剂による薬害に対しての薬害軽减剂の効果は，第2圈〜第6四のとお リであっ下。モり齐一十の通常使用量( $2 / g / a)$ の場合は，DDAA，TDAAおよC゙NA

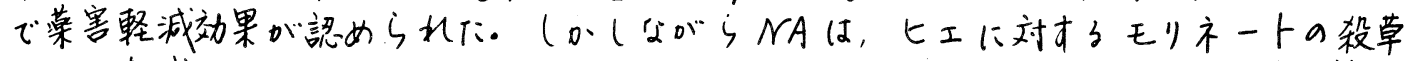

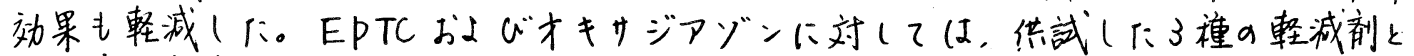

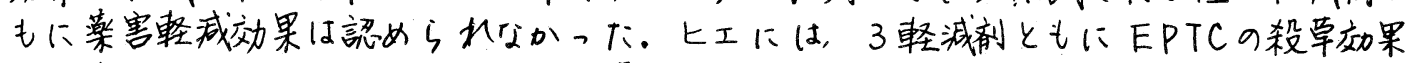
を埾减くたが、才キサジアゾンの殺草効果は助長(た。CNPSよびANK-553に対し ては，NAの从萝害整咸効果が認められた。七工には，CNPa処理量が2408/a9埸合

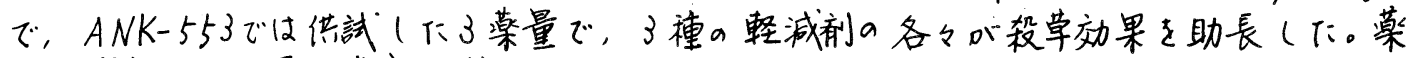
害軽减剂の処理量と菜害軽减効果との相関は，ANK-553 に対するNAで認められ下 以外は明らかで「ふかっ下。

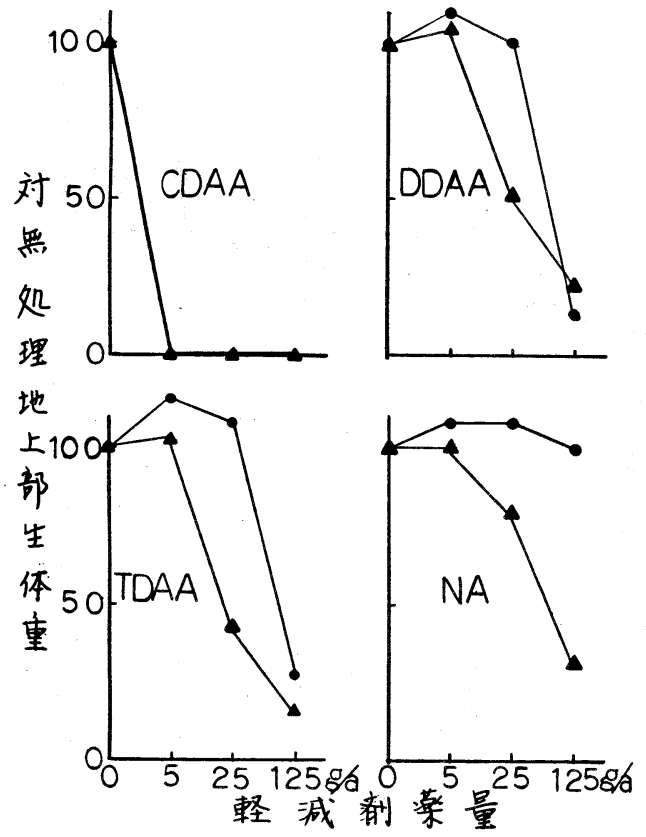

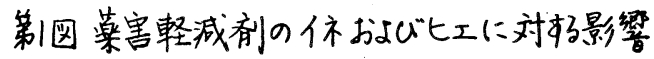

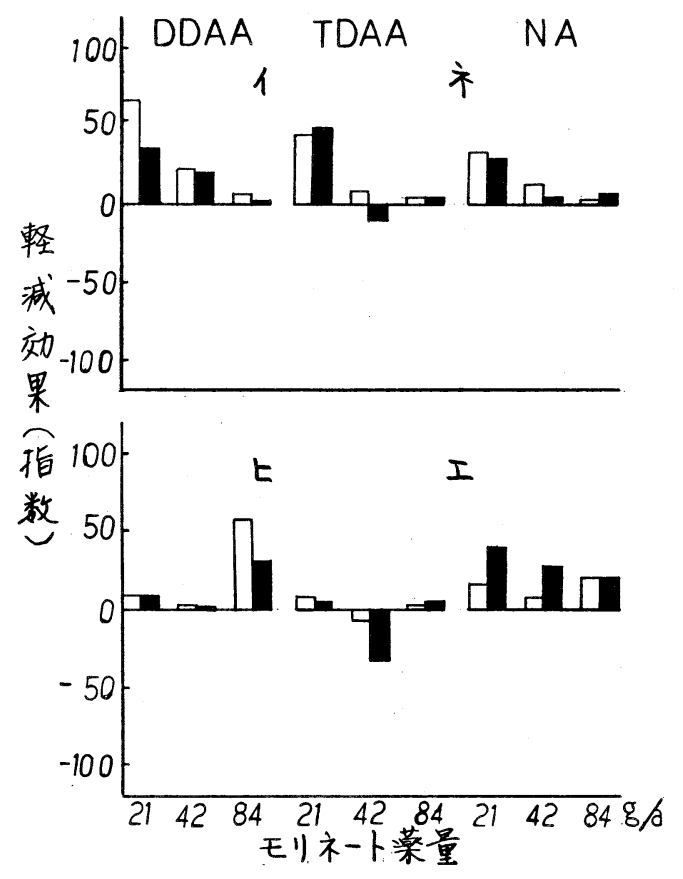

第2图モりネートに対する薬害埾减効果 軽减削処理量 58/a 整减㓱処理量 $25 \%$ 


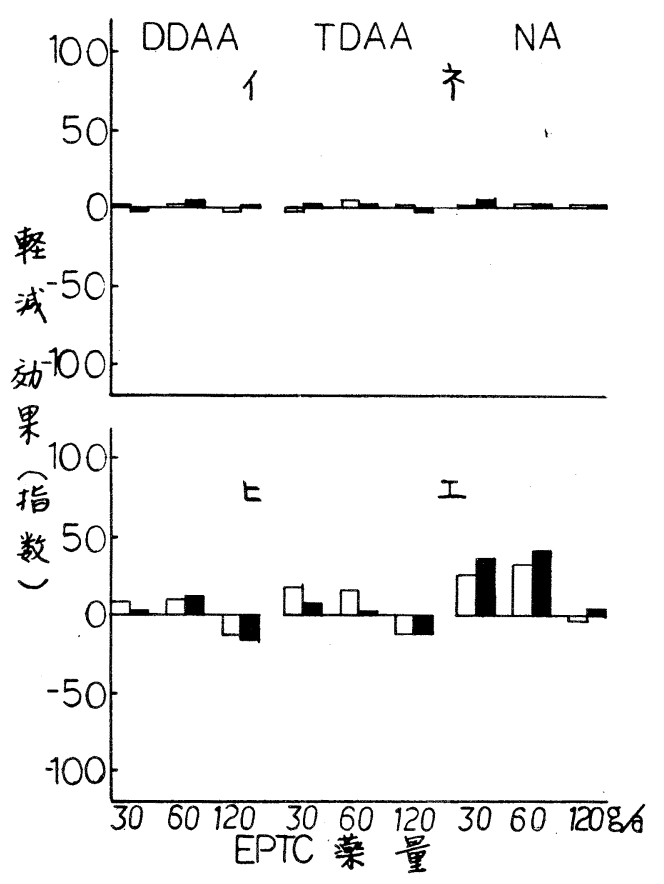

第3回EPTCに対す了菜害軽减効果

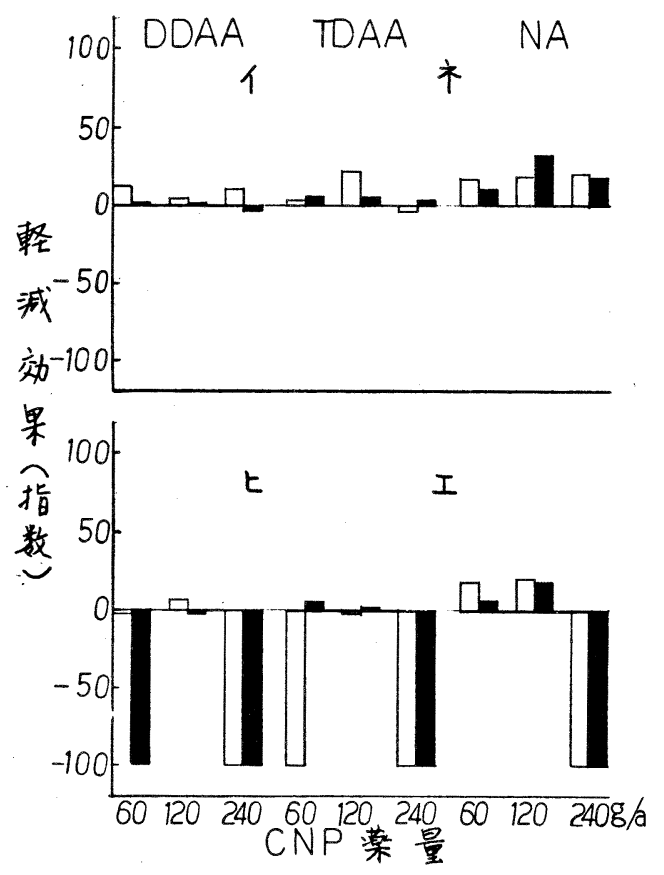

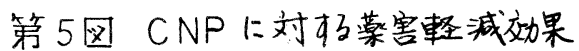

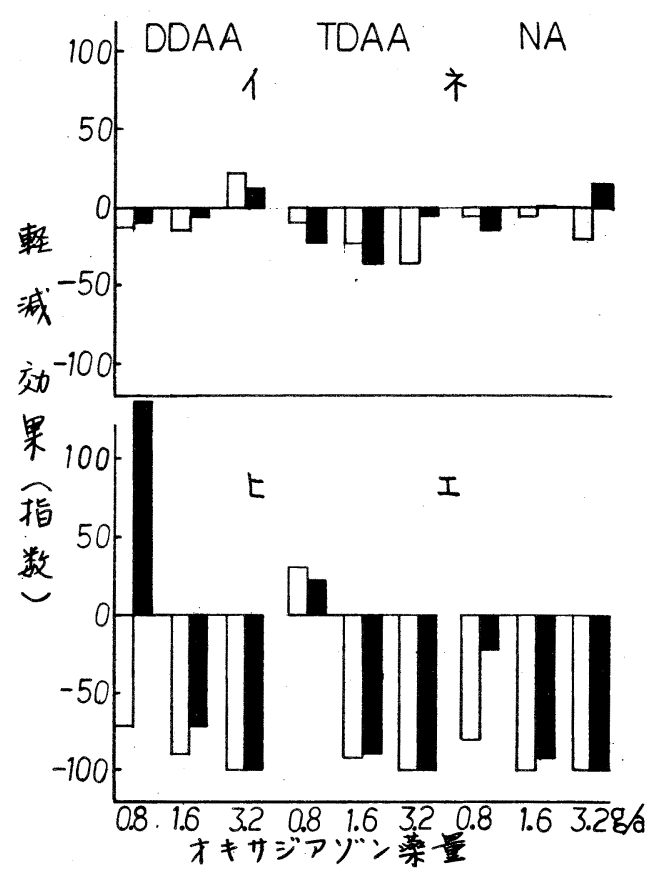

第4国 オキサジアリ゙ンに対する菜害埾减动果
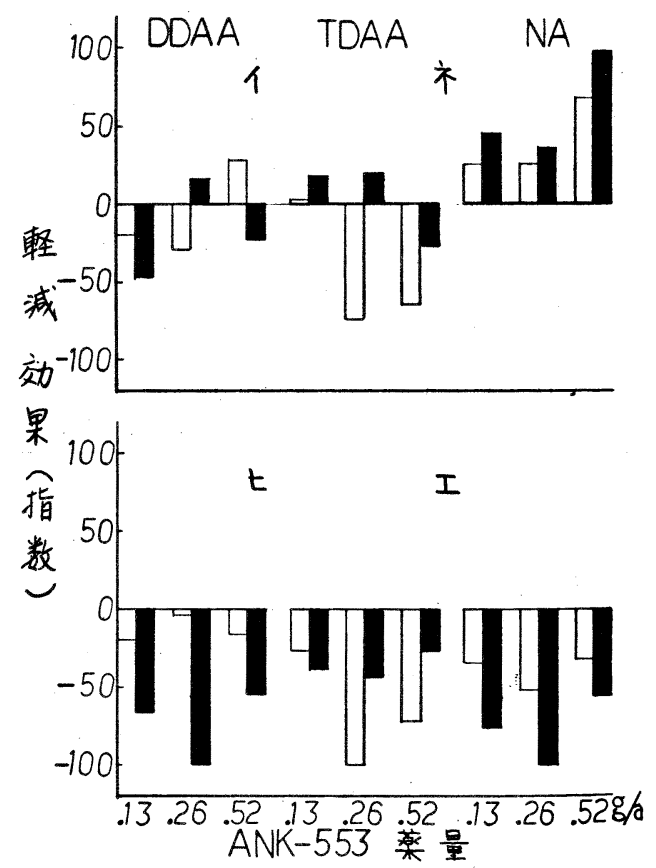

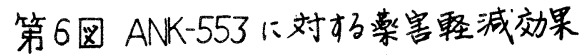


42. 水田土壤中に残留するCNPとNIPの全国実態調査

\section{山田忠男（䁐技研）}

ジフェニルエーテル系の除草郕CNP と NIPは, 水田土 壤中で比較的速く减少するが，二トロ基を退元されたアミ ，体が安定な結合形態で线留し，二トロ体とアミ，体の合 計量を求めると，菠城景の湿田できわめて残留量の多い例 も認められたことを昨年度報告した。

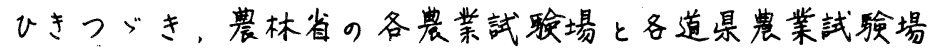
の協力を之て全国的に土壤を採取し、CNPの二トロ体と 阝ミ, 体, NIPのニト口体とアミ, 体の残留量を测定し

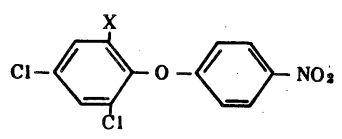

$\left\{\begin{array}{r}X=H, N I P \\ \text { CI, CNP }\end{array}\right.$ た。また，玄米中のCNP-P、 ，体とNIP-Pミ，体を測定し たので、これらの結果を報告す る.

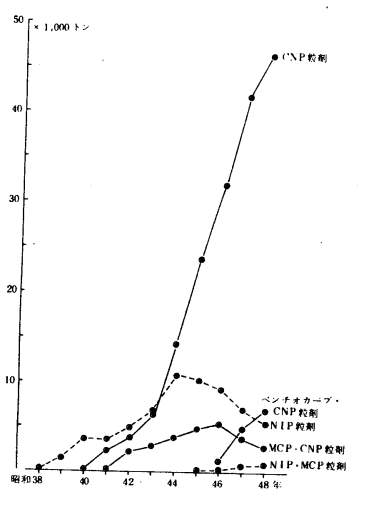

第1図 CNPあるいはNIPを含む製郕の 出荷量推移 (農薬要臨加作図)

\section{$\langle$ 方法〉}

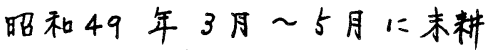
起水田の作土 $10 \mathrm{~cm}$ を採取し, 地表からの深さにようて2尼す るいは4アに分けて分析した。 採取した試雅区は 48 年度の CNP 散布38区，NIP 散布 1 区と無散布4区であった。

ニト口体の抽出と测定方法は 昨年度とほぼ同じでクつたじ 3因)。中5因総》ミ，体の 抽出方法を示した。二れは土填 に退元剂として $\mathrm{Na}_{2} S を$ 加之， 強いアルカリ処理を行ない二ト 口体も含めてマミ，体化しうる 残留物真をすべてヤミ，体とし て抽出する方法でする。総ヤミ 人体抽出液はトリフルオルア七 チル (TFA) 化l，GC (ECD)

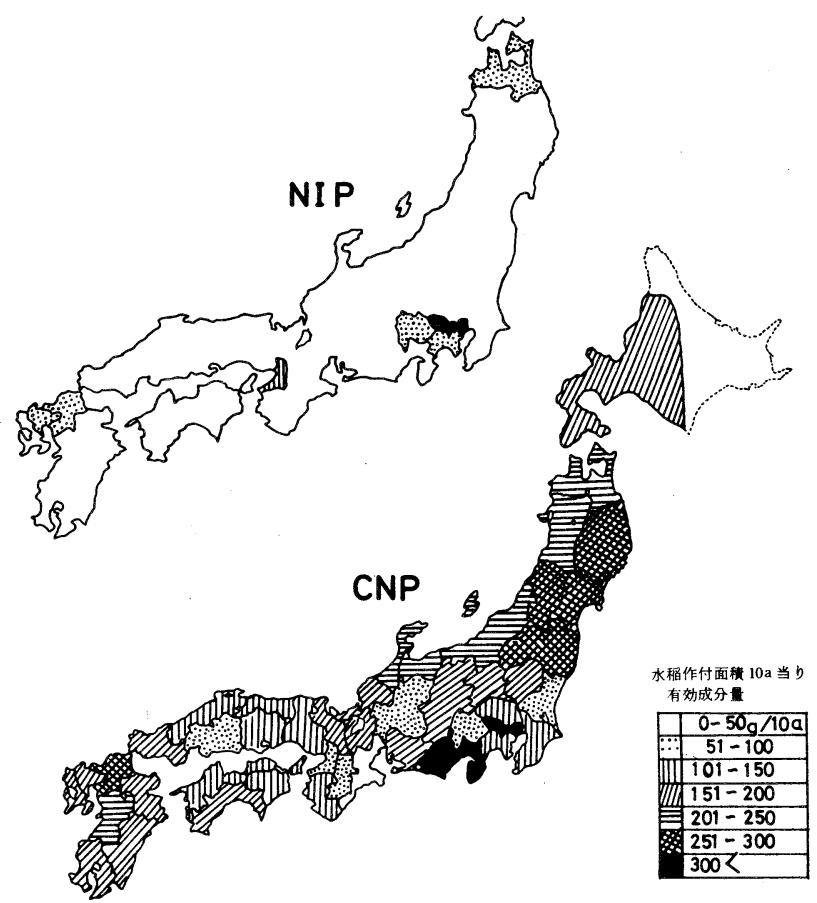

第 2 図昭和 48 年度における水田単位面積当りN I P と C N P の出荷量 （農薬要臨と農林省作物緒計加作図）

により测定したが、光のピー7

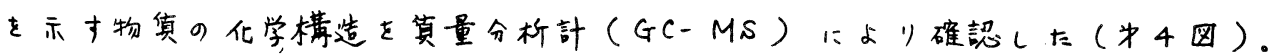

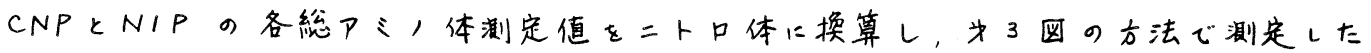
ニトロ体值を差引いてアミ, 体值( テトロ体换算值) を求めた。 

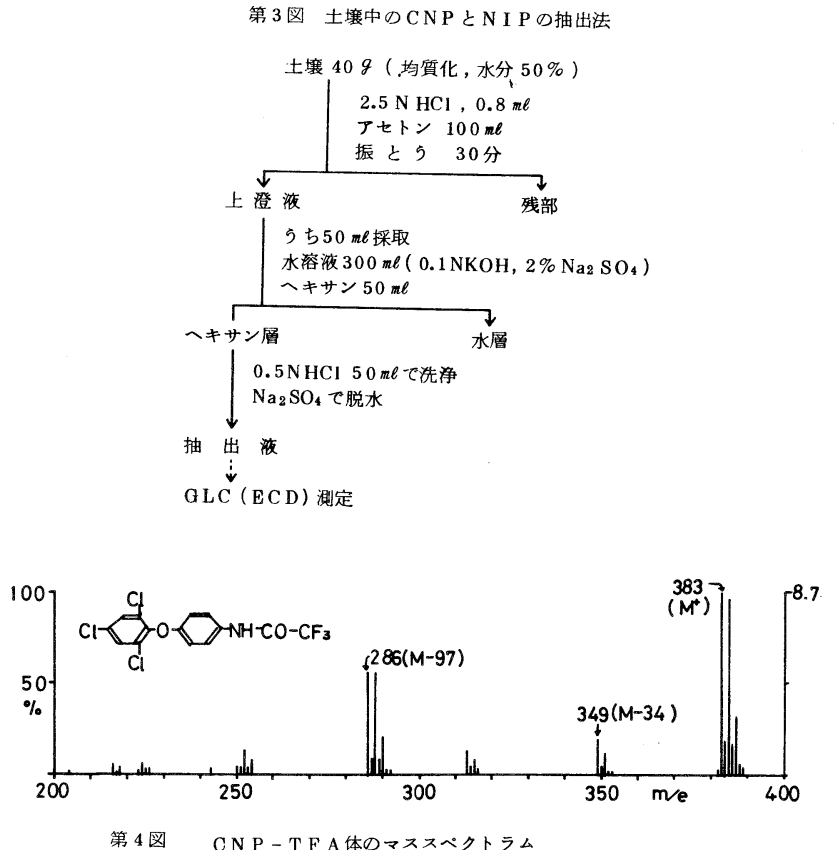

第 6 図玄米中のアミノ体抽出法

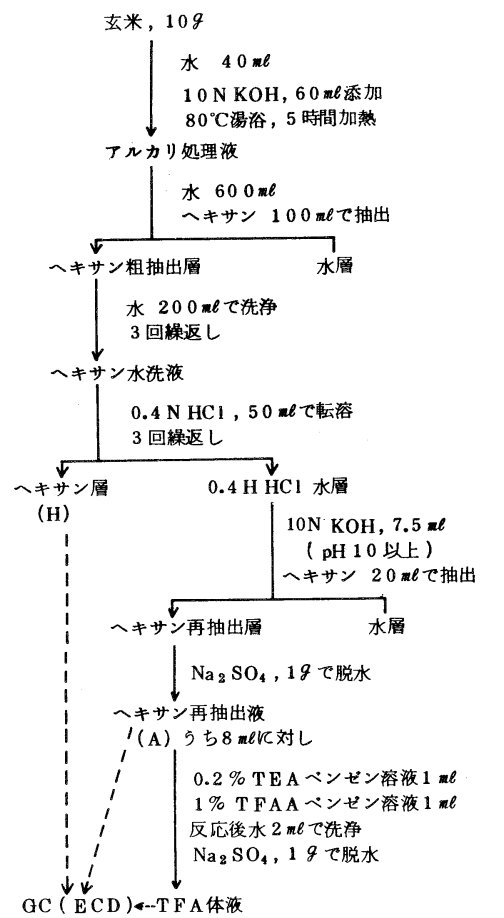

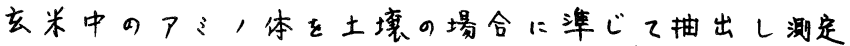
LE( 未 6 四)。GC力ラムに5\%OV-1を使用した 場合にはCNP-TFA体と重なるピークを生に゙たが, $10 \% D C-200$ を使用すると分離した。さらにGC-MS によりピーク物盾を確認した。

\section{〈結果〉}

1. 水田土壤(作土) 中には，48 年度CNP散布区はも 53 人，㩊散布区にもかなり多いCNPーアミ，体と 若干の=トロ体尔検出された。さらにNIP-P、， 体とニトロ体が検出された。榆出量は試呀区による 変動が大きい。

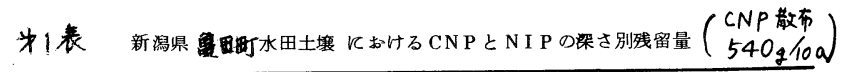

\begin{tabular}{|c|c|c|c|c|c|c|}
\hline \multirow{2}{*}{ 梁さ $(c m)$} & \multicolumn{3}{|c|}{ C N P 含量（ppm） } & \multicolumn{3}{|c|}{ N I P 含量（ppm） } \\
\hline & $=$ 上口体 & アミノ体 & 合 & 二トロ体 & アミノ体 & 合 \\
\hline $0 \sim 2.5$ & 0.07 & 4.01 & 4.08 & 0 & 0.44 & 0.44 \\
\hline $2.5 \sim 5.0$ & 0.03 & 2.84 & 2.87 & 0 & 0.44 & 0.44 \\
\hline $5.0 \sim 7.5$ & 0.01 & 2.10 & 2.11 & 0 & 0.40 & 0.40 \\
\hline $7.5 \sim 10.0$ & 0.01 & 1.93 & 1.94 & 0 & 0.40 & 0.40 \\
\hline $10 \sim 20$ & 0.01 & 0.93 & 0.94 & 0 & 0.22 & 0.22 \\
\hline $20 \sim 30$ & 0 & 0.03 & 0.03 & 0 & 0.07 & 0.07 \\
\hline $30 \sim 40$ & 0 & 0 & 0 & 0 & 0.10 & 0.10 \\
\hline
\end{tabular}




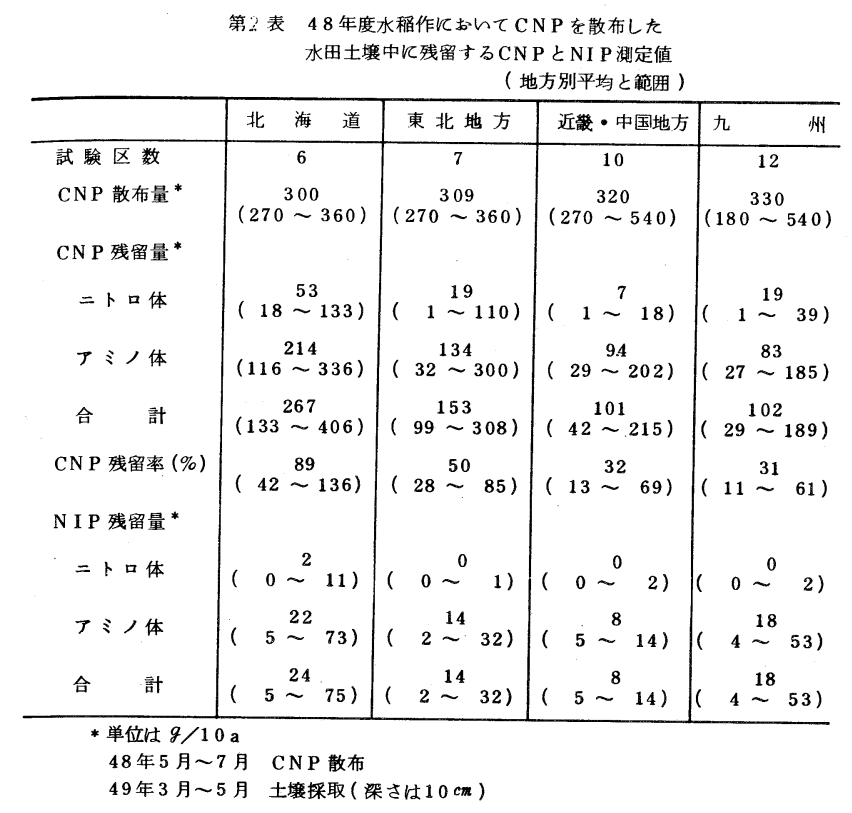

2. 48 年度 CNP 散布区のj 5 鴻果と新浮を除入了，地方 别に上壤中残留平均值を求中 て为乙表に示した。 北海道ではCNP - = ト口体 ，Pミ，体ともに多く，合計 残留率189\%でちつた。東 北地方が二れ儿次占，近裁。 中国地方と九州では：二れよ 》低く $32 \%$ と ア1\%ですっ E.

3.鸿策の乾田直播区で，CNP 9土壤中合計线留率 $121 \%$ と い广高”洌がろつた。 4 一般に土填中のニトロ体は ヤ、，体に比べ少なかつたが 少数例では二ト口体の方が多 “場合も認め引れ下。

5.NIP散布区の土壤中NIP残留率は、CNP散布区のCNP残留率とはば同じであ フた。最近NIPを散布していない区や全くNIPを散布していない区にもアミ,体を 主とするNIPが検出され，土壤条件によってCNPの退元的脱㦈素反忘が起ると推 定之れた。

6.GC-MSにより, 土壤から抽出测定されたPミ，体が，CNP-Pミ，体とNIP-P ミノ体である:とを確認した。

7. 玄米11種につ1て，CNP-Pミ，体とNIP-Pミ，体を抽出測定したが，いずれ も検出されなかった。この場合の检出限界は0.01 ppm であつた。 